\title{
ANALISIS KANDUNGAN LOGAM BERAT TIMBAL (Pb) PADA KAWASAN PERCETAKAN DI KOTA MEDAN
}

\section{ANALYSIS OF LEAD WEIGHT METAL (Pb) USING PHYTHOREMEDIATION METHOD IN PRINTING AREA IN MEDAN CITY}

\author{
Juwairiah $^{1^{*}}$ \\ ${ }^{1}$ Program Studi Teknik Grafika, Politeknik Negeri Media Kreatif, Medan, Indonesia \\ *Email: juwairiah@polimedia.ac.id
}

Diterima: 03 Februari 2021. Disetujui: 20 Maret 2021. Dipublikasikan: 22 April 2021

\begin{abstract}
Abstrak: Penelitian ini bertujuan untuk mengetahui kandungan logam berat Timbal $(\mathrm{Pb})$ pada tanaman kangkung air (Ipomoea aquatca) di kawasan percetakan Kota Medan. Penelitian ini bersifat deskriptif yaitu dengan mengambil sampel secara random, artinya tanaman kangkung air (Ipomoea aquatica) diambil secara acak pada kawasan percetakan di Kota Medan. Dari hasil penelitian ini didapatkan kadar Timbal $(\mathrm{Pb})$ pada tanaman kangkung air (Ipomoea aquatica) masih berada di bawah ambang batas yang ditentukan oleh Peraturan Menteri Pertanian Republik Indonesia Nomor 04/Permentan/Pp. 340/2/ 2015 Tentang Pengawasan Keamanan Pangan Terhadap Pemasukan Dan Pengeluaran Pangan Segar Asal Tumbuhan serta menurut SNI No.7387-2009, batas maksimum cemaran logam berat yang diperbolehkan dalam sayuran yakni batas ambang masimum $0,25 \mathrm{mg} / \mathrm{kg}$ untuk Timbal $(\mathrm{Pb})$. Sehingga kangkung air (Ipomoea aquatica) pada kawasan percetakan di Kota Medan masih aman untuk dikonsumsi masyarakat. Kadar Timbal $(\mathrm{Pb})$ pada kangkung air (Ipomoea aquatica) yang paling tinggi yaitu yang diperoleh dari Titik 1 yang berada di Jalan Masjid yakni $0,04497 \mathrm{mg} / \mathrm{kg}$ sedangkan kadar Timbal (Pb) yang paling rendah yaitu di Titik 2 yang berada di Jalan Padang Bulan yakni 0,02273 mg/kg.
\end{abstract}

Kata kunci : Timbal, Percetakan, Kangkung.

Abstract: This study aims to determine the content of the heavy metal lead $(\mathrm{Pb})$ in water spinach (Ipomoea aquatica) in the printing area of Medan City. This research is descriptive by taking samples randomly, meaning that water spinach plants (Ipomoea aquatica) were taken randomly from the printing area in Medan City. From the results of this study, it was found that the levels of Lead $(\mathrm{Pb})$ in water spinach (Ipomoea aquatica) were still below the threshold set by the Regulation of the Minister of Agriculture of the Republic of Indonesia Number 04/Permentan/Pp.340/2/2015 concerning Food Safety Supervision of the Importation and Exportation of Fresh Food from Plants and according to SNI No.7387-2009, the maximum limit of heavy metal contamination allowed in vegetables is a maximum threshold of $0.25 \mathrm{mg} / \mathrm{kg}$ for Lead $(\mathrm{Pb})$. So that the water spinach (Ipomoea aquatica) in the printing area in Medan is still safe for public consumption. The highest levels of Lead $(\mathrm{Pb})$ in water spinach (Ipomoea aquatica) are obtained from Point 1 on Jalan Masjid which is $0.04497 \mathrm{mg} / \mathrm{kg}$ while the lowest levels of Lead $(\mathrm{Pb})$ are at Point 2 which is on Jalan Padang Bulan that is $0.02273 \mathrm{mg} / \mathrm{kg}$.

Key words : Lead, Printing, Phytoremediation

\section{PENDAHULUAN}

Tingginya tingkat pencemaran logam berat di wilayah darat, air dan udara di beberapa wilayah di Indonesia perlu ditanggulangi demi mengurangi toksisitas terhadap manusia. Salah satu upaya untuk mengurangi pencemaran limbah adalah dengan metode fitoremediasi, yaitu menggunakan tanaman yang memiliki kemampuan tinggi untuk menyerap berbagai polutan (multiple uptake hyperaccumulator plant) atau menggunakan tanaman yang memiliki kemampuan mengangkut pencemaran bersifat tunggal (spesific uptake hyperaccumulator plant).

Fitoremediasi salah satu metode remediasi dengan mengandalkan pada peranan tumbuhan untuk menyerap, mendegradasi, mentransformasi dan mengmobilisasi bahan pencemar logam berat. Tanaman mempunyai kemampuan mengakumulasi logam berat yang bersifat esensial untuk pertumbuhan dan perkembangan [1]. Limbah percetakan mengandung logam berat yang terdiri dari Timbal (Pb), Krom (Cr), Cobalt (Co), Mangan (Mn) dan Timah (Sn). Timbal $(\mathrm{Pb})$ merupakan logam berat dengan konsistensi lunak dan berwarna hitam [2]. Kangkung merupakan salah satu tanaman yang mudah menyerap logam berat dari media tumbuhnya.

Akibat pencemaran yang terjadi pada air, udara maupun tanah yang digunakan sebagai media tanamnya, maka besar kemungkinan terjadi penyerapan logam berat pada tanaman kangkung tersebut. Salah satu logam berat yang banyak mencemari air sungai adalah timbal $(\mathrm{Pb})$ [3]. $\mathrm{Pb}$ di dalam tanah mempunyai kecenderungan terikat oleh bahan organik dan sering terkonsentrasi pada bagian atas tanah karena menyatu dengan tumbuhan, dan 
kemudian terakumulasi sebagai hasil pelapukan di dalam lapisan humus. $\mathrm{Pb}$ relatif dapat melarut dalam air dengan $\mathrm{pH}<5$ dimana air yang bersentuhan dengan timah hitam dalam suatu periode waktu dapat mengandung $>1 \mu \mathrm{g} \mathrm{Pb} / \mathrm{dm} 3$, sedangkan batas kandungan dalam air minum adalah $50 \mu \mathrm{g} \mathrm{Pb} / \mathrm{dm} 3$. Hal ini harus diwaspadai karena dapat mencemari lingkungan dengan akibat timbulnya berbagai penyakit berbahaya atau bahkan kematian.

Dampak lebih jauh dari keracunan $\mathrm{Pb}$ adalah dapat menyebabkan hipertensi dan salah satu faktor penyebab penyakit hati. Ketika unsur ini mengikat kuat sejumlah molekul asam amino, haemoglobin, enzim, RNA, dan DNA; maka akan mengganggu saluran metabolik dalam tubuh. Keracunan $\mathrm{Pb}$ dapat juga mengakibatkan gangguan sintesis darah, hipertensi, hiperaktivitas, dan kerusakan otak [4].

Jumlah $\mathrm{Pb}$ minimal didalam darah yang dapat menyebabkan keracunan berkisar antara 60-100 mikro gram per $100 \mathrm{ml}$ darah. Pada keracunan akut biasanya terjadi karena masuknya senyawa timbal yang larut dalam asam atau menghirup uap $\mathrm{Pb}$ tersebut. Gejala-gejala yang timbul berupa mual, muntah, sakit perut hebat, kelainan fungsi otak, anemia berat, kerusakan ginjal bahkan kematian dapat terjadi dalam 1-2 hari [5]. Menurut SNI No.7387-2009, batas maksimum cemaran logam berat yang diperbolehkan dalam sayuran adalah 0,5 $\mu \mathrm{g} / \mathrm{g}$ untuk timbal dan $0,2 \mu \mathrm{g} / \mathrm{g}$ untuk cadmium [6].

Penelitian yang telah dilakukan oleh Rumajar menunjukkan adanya kandungan logam berat timbal $(\mathrm{Pb})$ ini melebihi batas maksimum kadar logam berat timbal dalam sayuran untuk dikonsumsi yang ditetapkan oleh Badan Standardisasi Nasional Indonesia (BSNI) dan Badan Pengawasan Obat dan Makanan (BPOM) yaitu $0.5 \mathrm{mg} / \mathrm{kg}$. Bahkan suatu penelitian yang dilakukan oleh [7].

Hasil analisis karakteristik limbah cair industri percetakan yakni konsentrasi $\mathrm{Pb} 0,3 \mathrm{mg} / \mathrm{l}$. Konsentrasi ini melebihi baku mutu menurut Peraturan Pemerintah Negara Lingkungan Hidup Nomor 05 Tahun 2014 tentang Baku Mutu Air Limbah, yakni $\mathrm{Pb} 0,1 \mathrm{mg} / \mathrm{l}, \mathrm{Cr} 0,5 \mathrm{mg} / \mathrm{l}$ dan $\mathrm{Co} 0,4$ $\mathrm{mg} / \mathrm{l}$.

Peneliti mengambil sampel di dua tempat yaitu J1. Masjid, Kesawan, Kecamatan Medan Barat dan Jl. Jamin Ginting Padang Bulan, Kecamatan Medan Baru. Hal itu karena didaerah tersebut merupakan tempat percetakan terbesar di Kota Medan. Dan peneliti mencoba untuk menguji bagaimana keadaan limbah berat terkhusus timbal $\mathrm{Pb})$ dari limbah-limbah percetaka di kawasan tersebut.

Berdasarkan pemaparan di atas, peneliti tertarik untuk memeriksa logam berat timbal $(\mathrm{Pb})$ pada kangkung air (Ipomoea aquatica) yang ada pada kawasan percetakan di Kota Medan.

\section{METODE PENELITIAN}

\section{Bahan}

Bahan yang digunakan dalam penelitian adalah Kangkung Air (Ipomoea aquatica), $\mathrm{HNO}_{3}$ (Asam Nitrat) pekat (65\%), $\mathrm{HClO}_{4}$ (Asam Klorat) pekat dan Akuades.

Teknik Pengambilan Sampel di dua tempat Jl. Masjid, Kesawan Kecamatan Medan Barat dan Jl. Jamin Ginting, Padang Bulan, Kecamatan Medan Baru. Dilakukan secara random, yaitu daun dan batang tanaman kangkung air (Ipomea aquatica) diambil secara acak untuk kemudian dianalisis kandungan Timbal $(\mathrm{Pb})$ nya di Laboratorium Kesehatan Daerah Provinsi Sumatera Utara.

\section{Metode Penelitian}

Penelitian ini menggunakan metode deskriptif dgn cara survey eksploratif. Maka dalam hal ini kangkung air sebagai bahan penelitian. Penelitian bersifat deskriptif dengan cara survey eksploratif artinya dilakukan penelusuran langsung ke lapangan.

Metode Eksploratif adalah penelitian yang digunakan untuk mengumpulkan data-data awal tentang sesuatu ,Metode Deskriptif digunakan untuk mengkaji sesuatu seperti apa adanya (variabel tunggal) atau pola hubungan (korelasional) antara dua atau lebih variabel. "Penelitian eksploratif sendiri memiliki tujuan menggali secara luas tentang sebab-sebab atau hal-hal yang mempengaruhi terjadinya sesuatu" [8]. Jadi metode deskriptif eksploratif adalah penelitian dengan pemecahan masalah yang digali secara luas tentang sebab-sebab atau halhal yangmem pengaruhi terjadinya sesuatu berdasarkan fakta-fakta yang terjadi dilapangan. Teknik Pengambilan Sampel di kawasan industri percetakan di Kota Medan data yang dikumpulkan dalam penelitian ini didapat dari data primer yaitu dengan penelusuran langsung di Lapangan dan Perhitungan Kadar Timbal (Pb) di laboratorium.

\section{Prosedur Penelitian}

\section{a. Prosedur Kerja Di Lapangan}

1) Melakukan observasi di Lokasi Penelitian yakni di sekitar industri percetakan di Kota Medan.

2) Mengamati Morfologi Tanaman Kangkung Air (Ipomea aquatica) yang ditanam di sekitar industri percetakan di Kota Medan.

3) Melakukan pengulangan sebanyak 3 kali pada setiap lokasi. Sampel kangkung organik juga diambil hanya untuk mengetahui kadar unsur Timbal yang dikandung.

4) Memasukkan sampel ke dalam plastik bersih sehingga tidak terganggu dengan lingkungan luarnya serta diberi label dengan nama lokasi-lokasi tersebut. Sampel dicuci bersih dengan akuades. 
Kemudian diteliti di Laboratorium Kesehatan Medan untuk diteliti kadar Logam Berat Timbal $(\mathrm{Pb})$ nya.

5) Memisahkan sampel dengan menggunakan penggaris mengukur sebanyak $10 \mathrm{~cm}$ mulai dari pangkal batang ke tangkai daun yakni bagian tanaman Kangkung Air (Ipomea aquatica), serta membuat label pada sampel.

b. Prosedur Kerja Di Laboratorium

1) Sampel diperoleh dengan cara mengambil dari 2 titik yang ditanami dengan tanaman kangkung air (Ipomoea aquatica).

2) Setiap sampel ditimbang terlebih dahulu sebanyak 10 gr menggunakan neraca analitik, sampel yang diambil yakni bagian yang telah ditanami diukur $10 \mathrm{~cm}$ setiap bagian yang dimasukkkan ke dalam cawan porselen.

3) Sampel di Furnace dengan menggunakan alat furnace Giteca 48000 (pengabuan) sampel dengan suhu $600{ }^{\circ} \mathrm{C}$ selama 3 jam.

4) Setelah melakukan pem furnace an, kemudian melarutkan $500 \mathrm{ml}$ aquades dengan $50 \mathrm{ml}$ HNO3 pekat di dalam gelas Erlenmeyer.

5) Menambahkan larutan kedalam sampel hasil furnace hingga cawan terisi penuh.

6) Memanaskan perlahan-lahan sampel diatas hotplate hingga sisa volume contoh uji sebanyak $15 \mathrm{ml}-20 \mathrm{ml}$.

7) Mendinginkan sampel , menyaring dengan kertas saring whatman dan menambahkan aquades hingga volumenya mencapai $50 \mathrm{ml}$ dan memasukkan ke dalam tabung reaksi.

8) Menganalisa kadar Timbal ( $\mathrm{Pb}$ ) dengan menggunakan SSA .Dilanjutkan dengan membuat larutan standar Timbal dengan konsentrasi 0,300 mg/L ( Standard 1); $0,600 \mathrm{mg} / \mathrm{L} \quad$ (Standard 2) ; 0,900 $\mathrm{mg} / \mathrm{L}($ Standard 3) ; 1,200 (Standard 4).

\section{c. Teknik Analisis Data}

Untuk menguji kandungan logam berat Timbal $(\mathrm{Pb})$, peneliti merujuk pada artikel (Lumban Gaol, 1981) :

1) Akumulasi Logam Berat Timbal $(\mathrm{Pb})$ Data yang diperoleh kemudian ditabulasi dan disajikan dalam bentuk tabel. (Tabel 1)

2) Analisis Menggunakan Spektrofotometer Serapan Atom (SSA)

Analisis menggunakan Spektrofotometer Serapan Atom (SSA) dilakukan dengan langkah-langkah sebagai berikut: a) Alat spektrofotometer diatur dan dioptimalkan untuk pengukuran logam Timbal $(\mathrm{Pb})$.

b) Mengisapkan larutan standart satu per satu ke dalam alat spektrofotometer melalui pipa kapiler, kemudian membaca dan mencatat masing-masing serapan masuknya (absorbansi) mulai dari titik per titik sehingga membentuk kurva kalibrasi.

\section{d. Parameter Penelitian}

Parameter penelitian antara lain:

1) Analisis kandungan tanaman untuk mengetahui kadar logam berat Timbal (Pb) pada tanaman kangkung air (Ipomoea aquatica).

2) Morfologi tanaman kangkung air (Ipomea aquatica), Hasil pengamatan morfologi pada Tanaman Kangkung Air (Ipomoea aquatica) dimasukkan ke dalam Tabel. (Tabel 2)

\section{HASIL DAN PEMBAHASAN}

1. Hasil Pemeriksaan Laboratorium Kadar Timbal (Pb) Pada Kawasan Percetakan di Kota Medan

Hasil penelitian dari pengambilan sampel tanaman kangkung air (Ipomoea aquatica) yang diambil dari 2 titik lahan yang ditanami kangkung di kawasan percetakan di Kota Medan, dimana yang menjadi sampel penelitian adalah tanaman kangkung air (Ipomoea aquatica). Sebelum sampel dianalisis, sampel telah melalui beberapa proses yaitu sampel tanaman kangkung air (Ipomoea aquatica) terlebih dahulu diukur $10 \mathrm{~cm}$ bagian yang dikonsumsi dan preparasi sampel untuk kemudian dianalisis menggunakan Spektrofotometer Serapan Atom (SSA).

Kandungan Timbal $(\mathrm{Pb})$ pada seluruh sampel tanaman kangkung air (Ipomoea aquatica) yang berasal dari kawasan percetakan di Kota Medan dilakukan di UPT. Laboratorium Kesehatan Daerah Provinsi Sumatera Utara. Analisis kadar logam timbal $(\mathrm{Pb})$ yang terdapat pada 2 titik pengambilan sampel kangkung air (Ipomoea aquatica) dilakukan sebanyak tiga kali pengulangan pada setiap titik pengambilan sampel.

Kemudian dari tiga kali pengulangan tersebut dihitung hasil rata-rata supaya hasil yang diperoleh lebih akurat. Setelah dilakukan pemeriksaan sampel ternyata seluruh sampel kangkung air (Ipomoea aquatica) mengandung kadar logam berat Timbal $(\mathrm{Pb})$ namun tidak melampaui ambang batas yang telah ditetapkan oleh Peraturan Menteri Pertanian Republik Indonesia Nomor 04/Permentan/Pp.340/2/2015 Tentang Pengawasan Keamanan Pangan Terhadap Pemasukan Dan Pengeluaran Pangan 
Segar Asal Tumbuhan serta menurut SNI No.7387-2009, batas maksimum cemaran logam berat yang diperbolehkan dalam sayuran yakni batas ambang masimum $0,25 \mathrm{mg} / \mathrm{kg}$ untuk Timbal $(\mathrm{Pb})$.

Tabel 1. Hasil Perhitungan Kadar Logam Berat Timbal (Pb) pada Tanaman Kangkung Air (Ipomoea aquatica) di Kawasan Percetakan Kota Medan

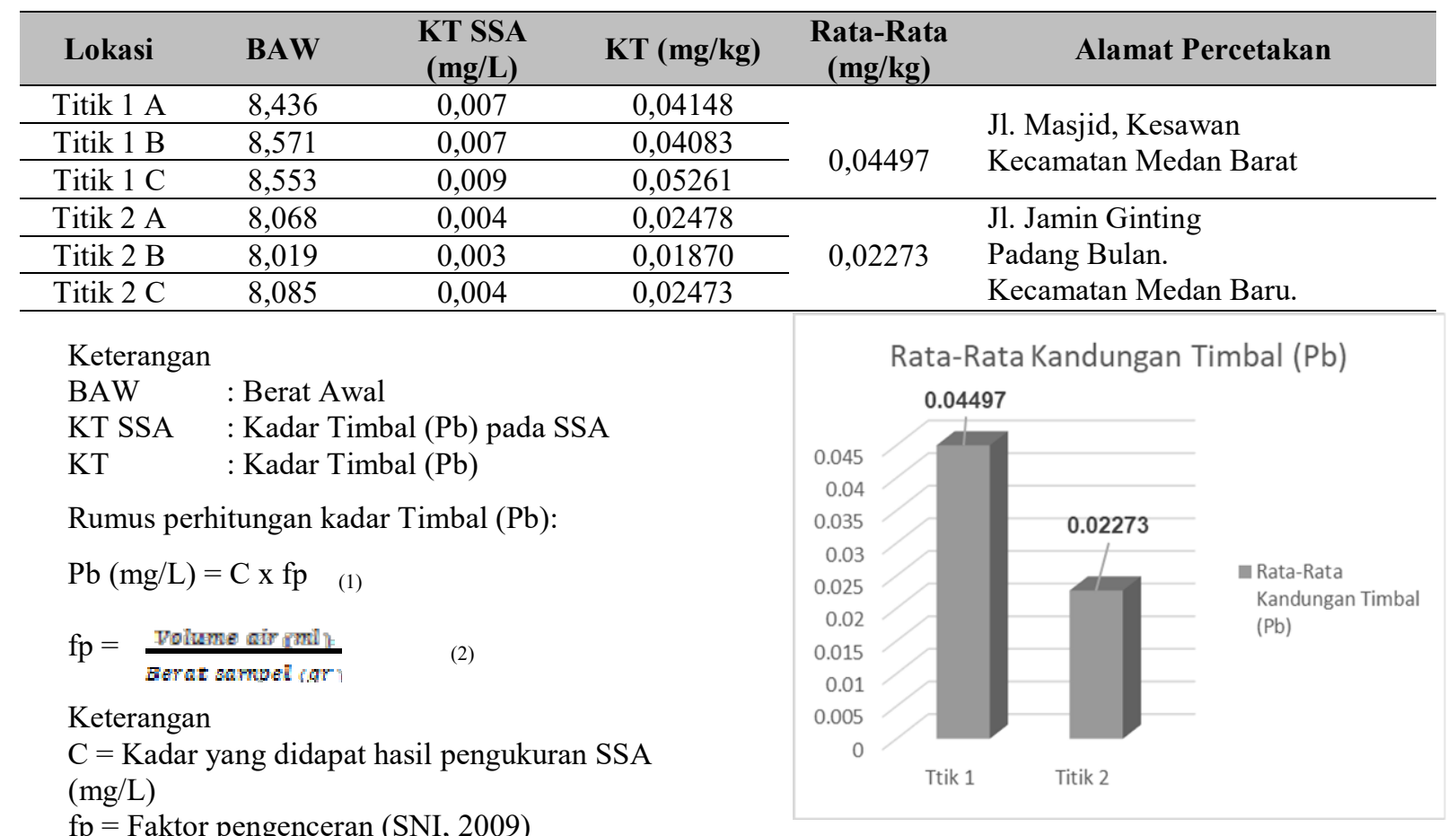

Berdasarkan hasil perhitungan Tabel 1. diketahui bahwa nilai absorbansi (serapan) yakni kadar timbal yang terbaca dalam mesin Spektrofotometer Serapan Atom (SSA) bahwa yang paling besar nilai absorbansi nya terdapat pada titik 1 ulangan ke 3 (C) yakni dengan nilai absorbansi sebanyak 0,009 mg/L.

Berdasarkan tabel diatas, dapat dilihat bahwa kadar rata-rata logam berat Timbal $(\mathrm{Pb})$ pada keenam sampel kangkung air (Ipomoea aquatica) yang diperiksa menggunakan Spektrofotometer Serapan Atom (SSA) berada di bawah ambang batas yang diatur dalam Peraturan Menteri Pertanian Republik Indonesia Nomor 04/Permentan/Pp.340/2/2015 Tentang Pengawasan Keamanan Pangan Terhadap Pemasukan Dan Pengeluaran Pangan Segar Asal Tumbuhan serta menurut SNI No.73872009, batas maksimum cemaran logam berat yang diperbolehkan dalam sayuran yakni batas ambang masimum $0,25 \mathrm{mg} / \mathrm{kg}$ untuk Timbal $(\mathrm{Pb})$.

Berdasarkan Tabel 1. Hasil akumulasi rata-rata kandungan logam berat yang paling banyak yaitu di Titik 1 yakni sebanyak 0,04497 $\mathrm{mg} / \mathrm{kg}$,sedangkan kadar kandungan logam berat Timbal $(\mathrm{Pb})$ yang paling sedikit terdapat pada Titik 2 yakni $0,02273 \mathrm{mg} / \mathrm{kg}$.
Gambar 1. Grafik Rata-Rata Logam Berat Timbal $(\mathrm{Pb})$ di 2 Titik Kawasan Percetakan Kota Medan

Berdasarkan Grafik 1. bahwa disetiap titik pengambilan sampel terdapat rata-rata kadar logam Timbal $(\mathrm{Pb})$ yang berbeda dan dilihat dari grafik tersebut terdapat kadar rata-rata logam berat Timbal (Pb) yang semakin meningkat antar per titik pengambilan sampel.

\section{Pembahasan Hasil Penelitian}

Berdasarkan Tabel 1. Adanya kadar Timbal $(\mathrm{Pb})$ pada tanaman Kangkung air (Ipomoea aquatica) di titik 1 dapat disebabkan oleh kandungan logam berat timbal di dalam tanah. Hal ini dikarenakan logam berat timbal pada tanah diserap oleh akar tanaman lalu masuk melalui akar ke jaringan tanaman. Tanaman Kangkung air (Ipomoea aquatica) merupakan tanaman semusim.

Hasil kandungan Timbal $(\mathrm{Pb})$ pada kangkung masih diambang batas wajar karena umur tanaman Kangkung air (Ipomoea aquatica) dapat dikatakan masih muda, sehingga belum menyerap sempurna logam Timbal $(\mathrm{Pb})$ dalam tanah. Akumulasi logam dalam jaringan dipengaruhi oleh umur, artinya fungsi dari organ tanaman kangkung air (Ipomoea aquatica) yang masih muda belum sepenuhnya berjalan dengan baik.

Membandingkan dari penelitian yang dilakukan oleh [7]. Hasil analisis karakteristik limbah cair industri percetakan yakni 
konsentrasi $\mathrm{Pb} \quad 0,3 \quad \mathrm{mg} / \mathrm{l}$. Konsentrasi ini melebihi baku mutu menurut Peraturan Pemerintah Negara Lingkungan Hidup Nomor 05 Tahun 2014 tentang Baku Mutu Air Limbah, yakni $\mathrm{Pb} 0,1 \mathrm{mg} / \mathrm{l}, \mathrm{Cr} 0,5 \mathrm{mg} / \mathrm{l}$ dan Co $0,4 \mathrm{mg} / \mathrm{l}$.

Hasil penelitian ini kandungan Timbal $(\mathrm{Pb})$ pada tanaman kangkung air (Ipomoea aquatica), hasil analisis laboratorium dengan menggunakan Spektrofotometer Serapan Atom (SSA) yang diperoleh dari beberapa titik pengambilan sampel yang berbeda-beda berkisar antara $0-0,4497 \mathrm{mg} / \mathrm{kg}$.

Lokasi pengambilan sampel yang terdapat di kawasan percetakan di Kota Medan dengan sumber pencemaran pembuangan sampah serta limbah percetakan.Tanaman kangkung air (Ipomoea aquatica) berada dalam batas aman untuk dikonsumsi. Hasil analisa yang berbeda dikarenakan lingkungan yang dikelilingi Logam berat Timbal $(\mathrm{Pb})$ memengaruhi proses fisiologi dan morfologi kangkung air, salah satunya penurunan laju pertumbuhan yang menyebabkan perbedaan peningkatan biomassa kangkung air.

Lingkungan logam Timbal membuat tanaman kangkung air melakukan adaptasi agar dapat bertahan hidup. Kebutuhan tanaman kangkung air akan nutrisi membuat tanaman ini menyerap logam berat timbal bersama hara dan selanjutnya logam berat timbal akan masuk ke jalur transpor bersama zat hara. Selanjutnya tanaman akan melakukan proses penetralan terhadap zat toksik dan mengeksresinya, hal ini sebagai bentuk adaptasi dan mekanisme penanggulangan dari kangkung air terhadap bahaya logam berat timbal. Selanjutnya akan ditranspor ke jaringan atau organ yang sudah tua seperti daun yang tua dan batang yang sudah kering. Proses ekskresi dapat dilakukan dengan cara menggugurkan daun yang sudah tua [1].

Dua jalan masuk logam berat ke dalam tumbuhan, yaitu melalui akar dan daun. Akar merupakan organ pada tum- buhan yang berfungsi sebagai organ penyerap dan penyalur unsur-unsur hara ke bagian lain. Sesuai dengan fungsinya, maka akar akan banyak menyerap unsur hara sehingga akumulasi logam akan lebih tinggi di akar dibandingkan dengan di bagian batang dan daun [3]. Pada kondisi lingkungan yang umum, timbal $(\mathrm{Pb})$ masuk pertama kali ke akar. Logam berat, dalam jumlah besar terpapar kelingkungan melalui limbah industri, sampah organik, pembakaran sampah, generator listrik dan emisi transportasi.

Logam berat dapat terbawa pada tempat yang jauh dari sumber dengan bantuan angin. Logam berat tidak dapat dihancurkan (non biodegradable), sekali logam berat tersebut masuk dalam tanah atau air akan menetap dalam jangka waktu lama [1].
Bahaya logam berat timbal $(\mathrm{Pb})$ dengan berbagai konsentrasi dan waktu dapat memengaruhi pertumbuhan kangkung air. Hal ini menunjukkan bahwa konsentrasi Timbal $(\mathrm{Pb})$ yang terdapat pada tanaman kangkung air (Ipomoea aquatica) masih dapat ditoleransi oleh tanaman kangkung air sehingga tidak menghambat pertumbuhannya. Tanaman ini tetap dapat tumbuh walaupun berada dalam lingkungan logam berat, namun laju pertumbuhan kangkung air pada setiap wilayah berbeda-beda.

Sumber pengambilan kangkung air (Ipomoea aquatica) di Titik 1 berada di Jl. Masjid, Kesawan Kecamatan Medan Barat, di Titik 2 Berada di Jl. Jamin Ginting, Padang Bulan. Kecamatan Medan Baru. Pada keracunan akut biasanya terjadi karena masuknya senyawa timbal yang larut dalam asam atau menghirup uap $\mathrm{Pb}$ tersebut. Gejalagejala yang timbul berupa mual, muntah, sakit perut hebat, kelainan fungsi otak, anemia berat, kerusakan ginjal bahkan kematian dapat terjadi dalam 1-2 hari [5]. Masuknya senyawa timbal ke dalam tubuh dapat menyebabkan gejala keracunan seperti gastrointestinal, rasa logam di mulut, sakit perut, muntah dan diare [7].

\section{Destruksi}

Destruksi ada dua yaitu destruksi kering dan destruksi basah. Dalam destruksi basah, bahan organik diuraikan dalam larutan oleh asam pengoksidasi pekat dan panas seperti $\mathrm{H}_{2} \mathrm{SO}_{4}, \mathrm{HNO}_{3}$ dan $\mathrm{HClO}_{4}$. Penambahan larutan pengoksidasi tersebut dilakukan untuk mempercepat proses destruksi. Penggunaan destruksi basah tertutup memberikan hasil yang lebih maksimal dalam penentuan kadar logam berat pada suatu sampel yang dianalisis dibandingkan dengan penggunaan destruksi basah terbuka. Hal ini diakibatkan oleh tidak adanya unsur-unsur volatil yang hilang ketika proses destruksi berlangsung.

Destruksi basah tertutup dapat diaplikasikan dengan menggunakan refluks atau microwave. Pemilihan metode destruksi tertutup terbaik dalam penentuan kandungan logam berat timbal $(\mathrm{Pb})$ pada sampel sangatlah penting karena berpengaruh terhadap hasil analisis. Destruksi basah tertutup dengan menggunakan microwave memakai bejana yang kedap sehingga waktu yang digunakan untuk mendestruksi sampel lebih singkat dan dalam satu kali proses dapat langsung mendestruksi 8 sampai 12 sampel. Sedangkan destruksi basah tertutup dengan refluks dilakukan dengan menggunakan labu alas bulat yang dilengkapi dengan kondensor pendingin yang dialiri oleh air dengan temperatur yang tetap harus dikontrol.

Destruksi dengan refluks dilakukan selama \pm 3 jam hingga larutan jernih [9]. Kontaminasi yang cukup besar dapat berasal dari crucible terbuka yang 
memungkinkan debu dari udara dan tungku dapat masuk.

\section{Penentuan Kadar Timbal (Pb) pada tanaman Kangkung air (Ipomoea aquatica)}

Penentuan kadar Timbal $(\mathrm{Pb})$ pada tanaman kangkung air (Ipomoea aquatica) dilakukan dengan menggunakan Spektofotometer Serapan Atom (SSA) dengan hellow cathode lamp yang sesuai dengan jenis logam yang dianalisis yaitu Timbal $(\mathrm{Pb})$.

\section{Morfologi Tanaman Kangkung Air (Ipomoea aquatica) pada kawasan percetakan Kota Medan}

Kangkung air (Ipomea aquatica) merupakan tumbuhan yang kebanyakan tumbuh di daerah tropis dan subtropis, Tanaman ini tumbuh dengan cara merambat dan dapat mengapung di atas air. Kangkung air termasuk tumbuhan yang mampu melakukan adaptasi dengan baik pada kondisi lingkungan dengan kisaran toleransi yang luas terhadap berbagai bahaya logam berat dan merupakan jenis tanaman hiperakumulator yang mampu menyerap logam pada konsentrasi tertentu.

Tabel 2. Morfologi Tanaman Kangkung Air (Ipomoea aquatica) pada kawasan percetakan di Kota Medan.

\begin{tabular}{|c|c|c|}
\hline Parameter & $\begin{array}{c}\text { Morfologi } \\
\text { Kangkung Air di } \\
\text { Titik } 1 \\
\end{array}$ & $\begin{array}{c}\text { Morfologi } \\
\text { Kangkung Air } \\
\text { di Titik } 2 \\
\end{array}$ \\
\hline $\begin{array}{l}\text { Warna } \\
\text { Daun }\end{array}$ & $\begin{array}{l}\text { Permukaan daun } \\
\text { sebelah atas } \\
\text { berwarna hijau tua } \\
\text { dan permukaan daun } \\
\text { sebelah bawah } \\
\text { berwarna hijau } \\
\text { muda }\end{array}$ & $\begin{array}{l}\text { Permukaan } \\
\text { daun sebelah } \\
\text { atas berwarna } \\
\text { hijau tua pekat } \\
\text { dan permukaan } \\
\text { daun sebelah } \\
\text { bawah berwarna } \\
\text { hijau }\end{array}$ \\
\hline $\begin{array}{l}\text { Bentuk } \\
\text { Daun }\end{array}$ & $\begin{array}{l}\text { Bentuk helaian daun } \\
\text { segitiga }\end{array}$ & $\begin{array}{l}\text { Bentuk helaian } \\
\text { daun seperti } \\
\text { membentuk } \\
\text { lengkungan }\end{array}$ \\
\hline Ujung Daun & Runcing & Runcing \\
\hline $\begin{array}{l}\text { Panjang } \\
\text { Tangkai } \\
\text { Batang } \\
\end{array}$ & $\pm 13 \mathrm{~cm}$ & $\pm 15 \mathrm{~cm}$ \\
\hline Ukuran & Daun muda $\pm 6 \mathrm{~cm}$ & $\begin{array}{l}\text { Daun muda } \pm 8 \\
\mathrm{~cm}\end{array}$ \\
\hline Daun & Daun Tua $\pm 18 \mathrm{~cm}$ & $\begin{array}{l}\text { Daun tua } \pm 23 \\
\mathrm{~cm}\end{array}$ \\
\hline $\begin{array}{l}\text { Warna } \\
\text { Batang }\end{array}$ & Hijau muda & Hijau muda \\
\hline
\end{tabular}

\section{KESIMPULAN DAN SARAN}

\section{A. Kesimpulan}

Berdasarkan hasil pemeriksaan kadar logam berat Timbal $(\mathrm{Pb})$ yang dilakukan terhadap tanaman kangkung air (Ipomoea aquatica) pada kawasan percetakan di Kota Medan dapat diambil kesimpulan bahwa:

Tanaman kangkung air (Ipomea aquatica) pada kawasan percetakan di Kota Medan mengandung cemaran logam berat Timbal $(\mathrm{Pb})$ yang masih di bawah ambang batas pecemaran. Seluruh sampel kangkung air (Ipomoea aquatica) yang dianalisis dengan menggunakan Spektrofotometer Serapan Atom (SSA) menunjukkan bahwa kadar logam Timbal $(\mathrm{Pb})$ yang terdapat pada tanaman kangkung air (Ipomoea aquatica) di Titik 1 dengan rata-rata sebanyak $0,04497 \mathrm{mg} / \mathrm{kg}$, Titik 2 dengan ratarata sebanyak $0,02273 \mathrm{mg} / \mathrm{kg}$, pada kawasan percetakan di Kota Medan berada dibawah ambang batas yang ditetapkan Peraturan Menteri Pertanian Republik Indonesia Nomor 04/Permentan/Pp.340/2/2015 Tentang Pengawasan Keamanan Pangan Terhadap Pemasukan Dan Pengeluaran Pangan Segar Asal Tumbuhan serta menurut SNI No.73872009, batas maksimum cemaran logam berat yang diperbolehkan dalam sayuran yakni batas ambang masimum $0,25 \mathrm{mg} / \mathrm{kg}$ untuk Timbal $(\mathrm{Pb})$.

\section{B. Saran}

Perlu dilakukan penelitian lanjut tentang jenis logam lain yang merupakan limbah percetakan mengandung logam berat seperti Krom (Cr), Cobalt (Co), Mangan (Mn) dan Timah (Sn) maupun logam berat lainnya.

\section{DAFTAR PUSTAKA}

[1] Lumban Gaol, D. M. (2018). Analisis Kandungan Logam Berat Kadmium (Cd) Pada Tanaman Kangkung Air (Ipomoea Aquatica) Dikawasan Industri Medan (Kim). 151(1), 1017.

[2] http://www.ncbi.nlm.nih.gov/pubmed/1728925 5\%0Ahttp://dx.doi.org/10.1016/j.jclepro.2011.1 0.008\%0Ahttp://www.uwaba.or.tz/National Ro ad Safety Policy September 2009.pdf\%0Ahtt p://dx.doi.org/10.1016/j.resconrec.2011.03.010 \%0Ahttp://dx.doi.org/10.1016/j.pecs.20

[3] Afrianita, R., \& Dewilda, Y. (2013). Efisiensi dan Kapasitas Penyerapan Fly Ash Sebagai Adsorben Dalam Penyisihan Logam Timbal $(\mathrm{Pb})$ Limbah Cair Industri Percetakan di Kota Padang. Jurnal Dampak, 10(1), 1. https://doi.org/10.25077/dampak.10.1.110.2013

[4] Hapsari, J. E., Amri, C., \& Suyanto, A. (2018). Efektivitas Kangkung Air (Ipomoea Aquatica) Sebagai Fitoremediasi Dalam Menurunkan Kadar Timbal $(\mathrm{Pb})$ Air Limbah Batik. Analit: Analytical and Environmental Chemistry, 9(4), 30-37.

https://doi.org/10.23960/aec.v3.i1.2018.p30-37

[5] Herman, D. Z. (2006). Tinjauan Terhadap Tailing Mengandung Unsur Pencemar Arsen (As), Merkuri (Hg), Timbal ( $\mathrm{Pb})$, dan Kadmium (Cd) dari Sisa Pengolahan Bijih Logam. 
Indonesian Journal on Geoscience, 1(1), 31-36. https://doi.org/10.17014/ijog.vol1 no1.20064a

[6] Rumajar, A. T. B. (2010). Penjajakan Kadar Logam Berat Pb Pada Tanaman Kangkung Darat Asal Kecamatan Medan Deli. 7-37.

[7] Badan Standardisasi Nasional. (2009). SNI 7387:2009. Batas Maksimum Cemaran Logam Berat dalam Pangan. In Batas Maksimum Cemaran Logam Berat dalam Pangan. https://sertifikasibbia.com/upload/logam_berat. pdf.

[8] Ihsan, T., Edwin, T., \& Vitri, R. Y. (2017). Analisis LC50 Logam Pb,Co dan Cr Terhadap Ikan Mas (Cyprinus carpio.L) Pada Limbah Cair Industri Percetakan Kota Padang. Jurnal Dampak, 14(2), 98. https://doi.org/10.25077/dampak.14.2.98103.2017

[9] Suharsimi Arikunto. (2011). Prosedur penelitian: Suatu pendekatan praktik/ Suharsimi Arikunto. Jakarta : Rineka Cipta

[10] Budianto, A. (2017). Analisis Kandungan Timbal (Pb) Pada Tanaman Kangkung Air (Ipomoea Aquatic Forrsk) Di Sungai Lesti Kabupaten Malang Dengan Variasi Metode Destruksi Basah Tertutup Menggunakan Spektroskopi Serapan Atom (SSA). 4, 9-15. 